\title{
Strong Impact Of Comprehensive Income On European Groups Listed In American Markets
}

\author{
Francisco Sousa Fernández, University of Cantabria, Spain
}

\begin{abstract}
The aim of this paper is to analyze the impact of Comprehensive Income on Net Income according to SFAS 130 issued by FASB for a sample of 136 corporate groups on the European continent listed in NYSE and NASDAQ for the period 1999-2004, taking as a reference the information contained in the reconciliation with US GAAP when they presented their accounts to the SEC. We have detected noticeable extreme values and outliers and, on average, marked negative effects on the groups considering the analysis detailed by size and industries, essentially motivated by the stock-exchange crisis of the early 2000's and by unfavorable exchange rates, particularly between the Euro and the U.S. dollar. All of this reveals the greater connection of Comprehensive Income with the reality of the markets than Net Income, which presumes that SFAS 130 issued by the FASB contributes to the increase of the relevance of the financial information in the performance area.
\end{abstract}

Keywords: Impact of Comprehensive Income on Net Income by Size and Industries; SFAS 130; European Groups Listed in NYSE and NASDAQ

\section{INTRODUCTION}

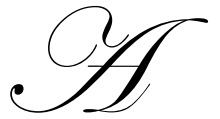

$\mathrm{s}$ is well known, U.S. companies are obliged to disclose Comprehensive Income in the main body of their periodic financial statements since the adoption of SFAS 130 (1997) issued by FASB. Taking into consideration the requirements of the SEC, companies in the rest of the world that trade in U.S. securities markets must disclose reconciliation of their financial statements to U.S. GAAP in Form 20-F filed with the SEC for foreign issuers, ${ }^{1}$ which is why they are obliged to disclose, in addition to other information, Comprehensive Income in accordance with the above-mentioned regulation.

Given the increased interest in the disclosure of Comprehensive Income for the users of financial information in an economy that is more and more internationalized, particularly for CPAs, academics, analysts and investors - even beyond U.S. borders, we have decided to analyze the impact of such disclosure on Net Income according to SFAS 130 for a sample of 136 corporate groups on the European continent listed in NYSE and NASDAQ for the period 1999-2004, taking as a reference the information contained in the reconciliation with U.S. GAAP when they presented their accounts to the SEC.

We have detected noticeable extreme values and outliers and, on average, marked negative effects on the groups considering the analysis detailed by size and industries, essentially motivated by the stock-exchange crisis of the early 2000's and by unfavorable exchange rates, particularly between the Euro and the U.S. dollar.

\section{SAMPLE}

We have confined our study to the period 1999-2004 in order to include the largest number of corporate groups in the sample. The problem, on the one hand, is that although SFAS 130 was approved at the end of 1997, certain companies did not trade in these markets in 1997 and 1998. On the other hand, since the first of January of 
2005, the listed companies of the European Union, for the formulation of their consolidated financial statements, had to apply the IFRS of the IASB. In this normative body, the disclosure of Comprehensive Income is already considered, specifically in IAS 1 (2003), under "Total Recognized Income and Expense", and certain companies in the reconciliation with U.S. GAAP in 20-F filed with the SEC, decided not to include Comprehensive Income when making it equivalent with that disclosed according to IASB GAAP, although they do not actually agree in all aspects.

Nevertheless, to homogenize the information, we had to apply the corresponding filters, which led us to exclude certain corporate groups from the listed companies on the European continent in NYSE and NASDAQ on 31 December 2004.

The reasons for excluding them were fundamentally: The companies were not listed the entire period from 1999-2004, they did not disclose Comprehensive Income in a clear way, or formulated their financial statements on a date different than the 31 of December (the majority being British companies). We are thus able to make consistent comparisons when linking Comprehensive Income with the prices of the securities and currency markets. Working with information related to different dates would distort the analysis.

After making these considerations, in Table 1 we collected the sample in which 136 corporate groups of 19 European countries are integrated, which represents $56 \%$ of the total listed companies on the European continent in NYSE and NASDAQ on 31 December 2004.

Table 1: Corporate Groups of the Sample Divided into Different Countries

\begin{tabular}{|c|c|c|}
\hline COUNTRY & $\begin{array}{c}\text { Number of } \\
\text { corporate groups }\end{array}$ & $\begin{array}{l}\text { Percentage of corporate groups of the the sample out of the } \\
\text { total number of European listed companies in NYSE and } \\
\text { NASDAQ on } 31 \text { December } 2004\end{array}$ \\
\hline Austria & 1 & $100 \%$ \\
\hline Belgium & 2 & $100 \%$ \\
\hline Denmark & 1 & $25 \%$ \\
\hline Finland & 3 & $75 \%$ \\
\hline France & 20 & $71 \%$ \\
\hline Germany & 10 & $59 \%$ \\
\hline Greece & 4 & $67 \%$ \\
\hline Hungary & 1 & $100 \%$ \\
\hline Ireland & 5 & $45 \%$ \\
\hline Italy & 9 & $90 \%$ \\
\hline Luxemburg & 4 & $67 \%$ \\
\hline Netherlands & 24 & $73 \%$ \\
\hline Norway* & 4 & $67 \%$ \\
\hline Portugal & 2 & $100 \%$ \\
\hline Spain & 7 & $89 \%$ \\
\hline Sweden & 3 & $60 \%$ \\
\hline Switzerland * & 12 & $80 \%$ \\
\hline Turkey $*$ & 1 & $100 \%$ \\
\hline United Kingdom & 23 & $30 \%$ \\
\hline Total......... & 136 & $56 \%$ \\
\hline
\end{tabular}

* These countries do not belong to the European Union Source: authors' calculations, from the listed companies in NYSE and NASDAQ and Form 20-F of the SEC. 


\section{IMPACT OF COMPREHENSIVE INCOME ON NET INCOME FOR EUROPEAN GROUPS LISTED IN NYSE AND NASDAQ IN THE PERIOD 1999-2004}

Comprehensive Income is defined in SFAC 6 (FASB, 1985, paragraph 70) as "the change in equity (net assets) of a business enterprise during a period from transactions and other events and circumstances from nonowner sources. It includes all changes in equity during a period, except those resulting from investments by owners and distributions to owners".

In accordance with SFAS 130 (FASB, 1997), Comprehensive Income is determined aggregating Net Income to "Other Comprehensive Income items", including Foreign Currency Translation Adjustments, Unrealized Gains/Losses on Securities, Minimum Pension Liability Adjustment, and also the gains and losses associated to certain operations with Derivatives and Cash Flow Hedges included when the corresponding regulations were approved by the FASB.

In order to analyze the impact of Comprehensive Income on Net Income, we must define the variable IMPACT OCI $=[$ OCI $/|\mathrm{NI}| \cdot 100]$ which expresses the percentage discrepancy of "Other Comprehensive Income" (OCI) compared with Net Income (NI); and since both OCI and NI can display either positive or negative values, we use absolute values in the denominator so that the reality of the discrepancy is shown in all cases, both positive and negative.

As one can infer from the previous expression we are attempting to evaluate the impact of the market on corporate groups limited to items included in "Other Comprehensive Income", as required by SFAS 130, compared to Net Income.

The first approach we see in Table 2 and in Graphic 1 is that for the mean of the 136 corporate groups included in the sample, belonging to 19 European countries and of all the industries, "Other Comprehensive Income" has affected corporate groups in a negative way since its results have worsened by more than $25 \%$, particularly during the years 2005 and 2006 when noticeable negative percentages were almost $-55 \%$ and $-94 \%$ respectively, due to the strong impact of the stock-exchange crisis of the early 2000's and unfavorable exchange rates in international business, particularly between the Euro and the U.S. dollar. ${ }^{2}$

Table 2: Impact of Means of "Other Comprehensive Income" on Net Income

Consolidated values, expressed in percentage terms and calculated using the expression IMPACT OCI $=[$ OCI $/ \mid$ NI $\mid \cdot 100]$

\begin{tabular}{|c|c|c|c|c|c|c|c|}
\hline $\mathbf{N}$ & $\mathbf{1 9 9 9}$ & $\mathbf{2 0 0 0}$ & $\mathbf{2 0 0 1}$ & $\mathbf{2 0 0 2}$ & $\mathbf{2 0 0 3}$ & $\mathbf{2 0 0 4}$ & $\begin{array}{c}\text { Average } \\
\mathbf{1 9 9 9 - 2 0 0 4}\end{array}$ \\
\hline 136 & 15.41 & -10.96 & -54.87 & -93.56 & 10.09 & -18.26 & -25.36 \\
\hline
\end{tabular}

Source: authors' calculations, based on the database and SPSS v.15.

\section{Individualized Impact Of The Components Included In "Other Comprehensive Income"}

Once the behavior of Comprehensive Income on Net Income has been globally analyzed, we propose to carry out a more detailed study. We will therefore consider the relative importance of each one of the elements that include "Other Comprehensive Income" compared with Net Income.

We can thus observe in Table 3 and in Graphic 2 that the items with, on average, the deepest impact in relative terms compared to Net Income are Foreign Currency Translation Adjustments with a negative effect of around $-15 \%$, followed by the Minimum Pension Liability Adjustment item of around $-8 \%$ and the Unrealized Gains and Losses on Securities close to -5\%, whereas the impact of Derivatives and Cash Flow Hedges has registered a positive percentage of less than $1 \%$. 
Graphic 1: Profile of the Impact of Means of "Other Comprehensive Income" on Net Income

Consolidated values, expressed in percentage terms and calculated using the expression IMPACT OCI $=[\mathrm{OCI} /|\mathrm{NI}| \cdot \mathbf{1 0 0}]$

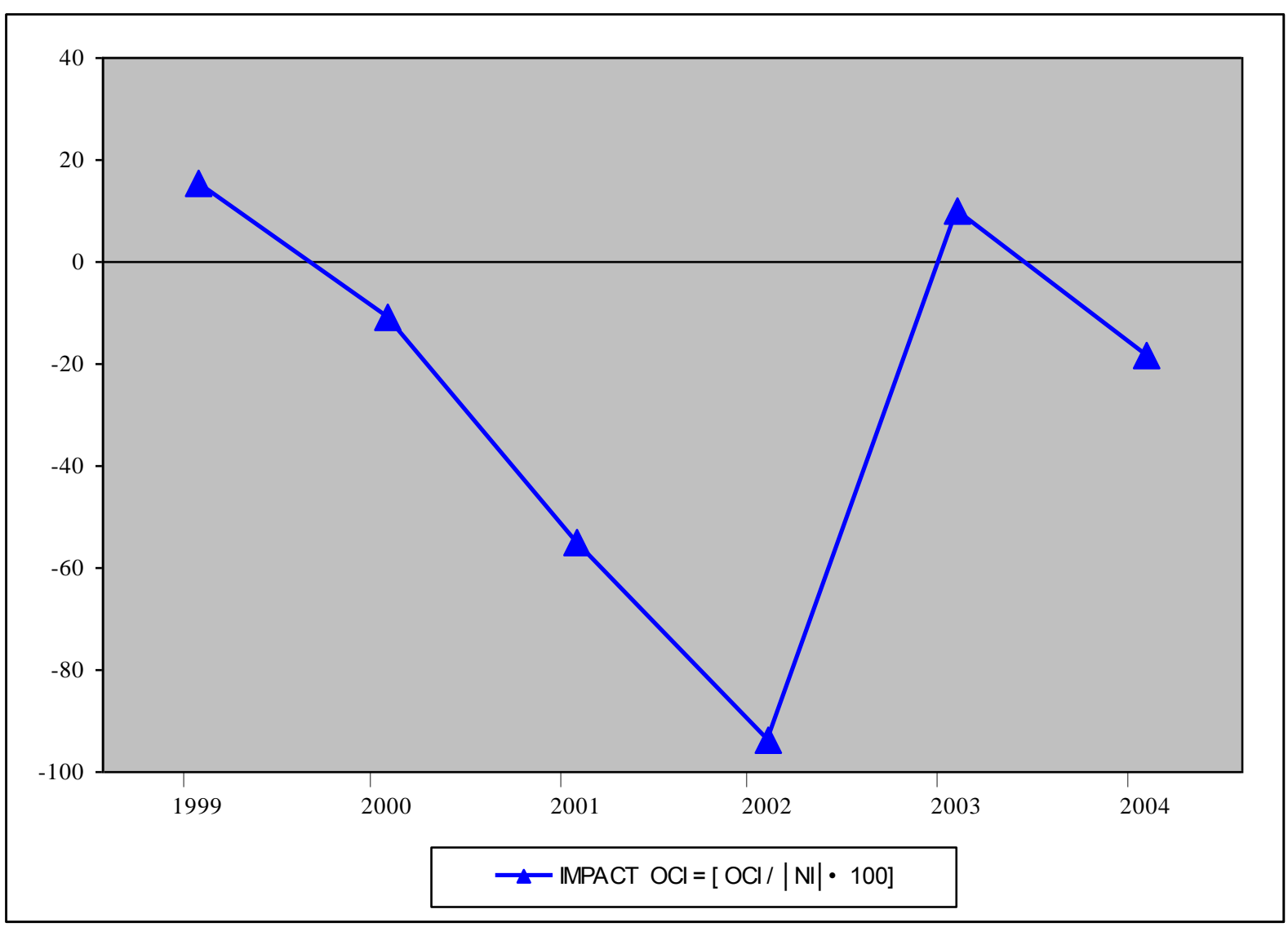

Source: authors' calculations, based on the database and SPSS v.15.

Table 3: Impact of Means of "Other Comprehensive Income" Items Considered Individually on Net Income ${ }^{3}$

Consolidated values, expressed in percentage terms and calculated using the expression IMPACT OCI $=[\mathrm{OCI} /|\mathrm{NI}| \cdot \mathbf{1 0 0}]^{4}$

\begin{tabular}{|c|c|c|c|c|c|}
\hline $\mathbf{N}$ & Years & $\begin{array}{c}\text { Foreign } \\
\text { Currency } \\
\text { Translation } \\
\text { Adjustments }\end{array}$ & $\begin{array}{c}\text { Unrealized Gains and } \\
\text { Losses on Securities }\end{array}$ & $\begin{array}{c}\text { Minimum Pension } \\
\text { Liability Adjustment }\end{array}$ & $\begin{array}{c}\text { Derivatives and } \\
\text { Cash Flow Hedges }\end{array}$ \\
\hline 136 & 1999 & -3.90 & 19.77 & 0.45 & -1.49 \\
\hline 136 & 2000 & -4.00 & -6.36 & -0.50 & 0.38 \\
\hline 136 & 2001 & -9.15 & -31.25 & -16.34 & -1.58 \\
\hline 136 & 2002 & -39.27 & -23.48 & -37.99 & 2.12 \\
\hline 136 & 2003 & -19.22 & 13.68 & -11.48 & 4.01 \\
\hline 136 & 2004 & -13.47 & -0.90 & -3.54 & 0.43 \\
\hline & Mean & -14.84 & -4.76 & -7.74 & 0.65 \\
\hline
\end{tabular}

Source: authors' calculations, based on the database and SPSS v.15. 
Graphic 2: Profile of the Impact of Means of "Other Comprehensive Income" Items considered Individually on Net Income

$$
\begin{aligned}
& \text { Consolidated values, expressed in percentage terms and calculated using the expression } \\
& \text { IMPACT OCI }=[\text { OCI } /|\mathrm{NI}| \cdot 100]
\end{aligned}
$$

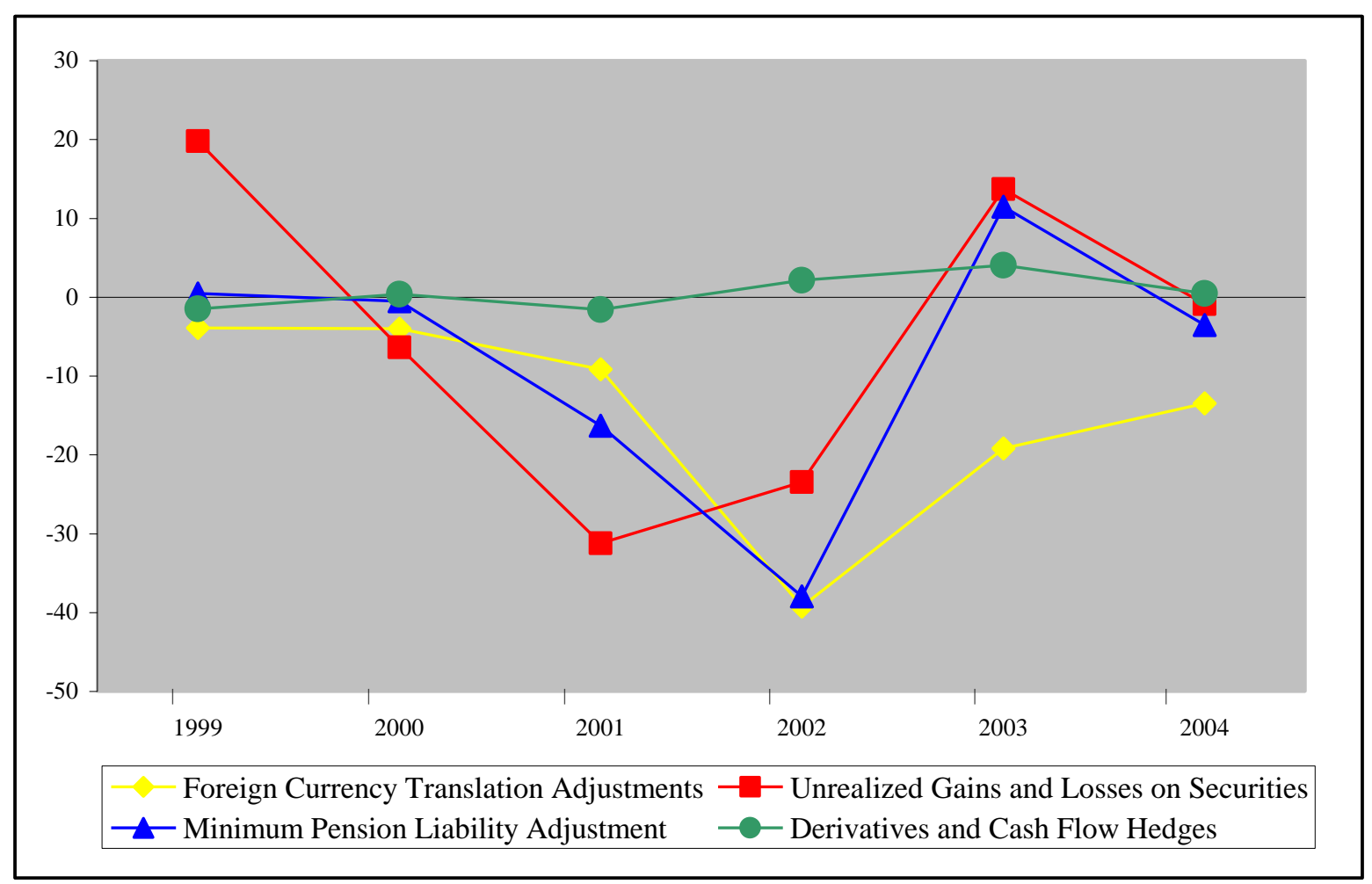

Source: authors' calculations, based on the database and SPSS v.15.

On the other hand, it is clearly shown that the most noticeable negative discrepancies for the group of items were registered on 2001 and 2002, a fact that, given the stock-exchange crisis of the early 2000's and the unfavorable exchange rates for the sample group of listed companies in their international operations, particularly between the Euro and the U.S. dollar, demonstrates the sensitivity of Comprehensive Income compared with market reality.

\section{Impact By Size}

Now we would like to analyze the impact of "Other Comprehensive Income" elements on Net Income, keeping in mind the size of the corporate groups for which we used the mean of employees of each corporate group in the period 1999-2004 as a reference, as shown in Table 4, even though similar statistical results were obtained when taking other references of size, such as total assets, turnover or equity.

Table 4: Size of Groups According to the Number of Employees

\begin{tabular}{|ll|r|c|}
\hline \multicolumn{3}{|c|}{ Levels per size } & Number of Corporate Groups \\
\hline Level 1 & Small & $0-4,267$ Employees & 45 \\
\hline Level 2 & Medium & $4,267-28,686$ Employees & 46 \\
\hline Level 3 & Large & $28,686-391,544$ Employees & 45 \\
\hline
\end{tabular}

Source: authors' calculations, based on the database and SPSS v.15. 
Table 5 and Graphic 3 show the impact by size of "Other Comprehensive Income" elements on Net Income. It can be observed that the small-sized corporate groups have registered a positive effect of more than $8 \%$ on average. However, as the corporate groups increase in size, the related impact becomes negative, reaching the point where medium-sized organizations experience declining results of around $-26 \%$ and large-sized organizations of almost $-58 \%$.

Table 5: Impact of Means by Size of "Other Comprehensive Income" on Net Income

Consolidated values, expressed in percentage terms and calculated using the expression IMPACT OCI $=[$ OCI $/|\mathrm{NI}| \cdot \mathbf{1 0 0}]$

\begin{tabular}{|c|c|c|c|c|c|c|c|c|}
\hline SIZE & $\mathrm{N}$ & $\mathbf{1 9 9 9}$ & $\mathbf{2 0 0 0}$ & $\mathbf{2 0 0 1}$ & $\mathbf{2 0 0 2}$ & $\mathbf{2 0 0 3}$ & $\mathbf{2 0 0 4}$ & $\begin{array}{c}\text { Average } \\
\mathbf{1 9 9 9 - 2 0 0 4}\end{array}$ \\
\hline Small & 45 & 17.62 & 0.35 & 3.18 & 31.91 & 13.01 & -15.59 & 8.41 \\
\hline Medium & 46 & -12.09 & -18.24 & -19.32 & -121.31 & 36.01 & -24.40 & -26.56 \\
\hline Large & 45 & 41.30 & -14.84 & -149.26 & -190.66 & -19.33 & -14.64 & -57.91 \\
\hline \multicolumn{2}{|l}{ Means by years } & 15.41 & -10.96 & -54.87 & -93.56 & 10.09 & -18.26 & -25.36 \\
\hline
\end{tabular}

Source: authors' calculations, based on the database and SPSS v.15.

Graphic 3: Profile of the Impact of Means by Size of "Other Comprehensive Income” on Net Income Consolidated values, expressed in percentage terms and calculated using the expression IMPACT OCI $=[$ OCI $/|\mathrm{NI}| \cdot 100]$

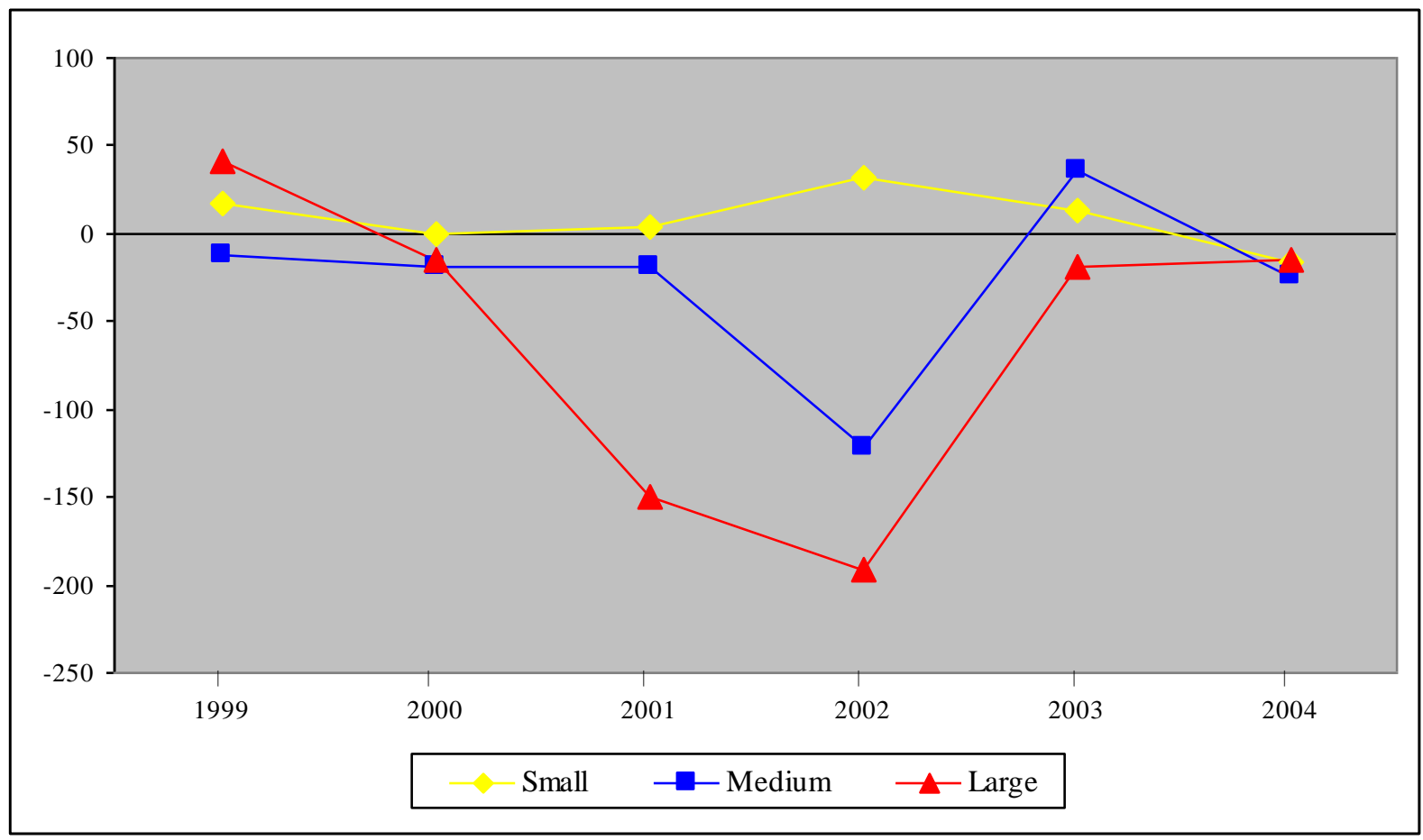

Source: authors' calculations, based on the database and SPSS v.15.

Furthermore, another fact to emphasize is that, on average, the small-sized corporate groups have been more immune to the stock-exchange crisis and to the unfavorable exchange rates of the early 2000's in the fact that 
"Other Comprehensive Income" has impacted them positively on average. Medium and large-sized groups, however, experienced considerable negative effects because of falls in the stock-exchange and unfavorable exchange rates, which is why Comprehensive Income in the context we are studying clearly makes a different impact depending on the size of the corporate group.

On the other hand, in Table 6 appear, marked with an asterisk $(*)$, the extreme scores, which are defined as scores that are greater than 3 box lengths away from the upper or lower edge of the box, and marked with a circle (०), the outliers, which are defined as scores that are between 1.5 and 3 box lengths away from the upper or lower edge of the box.

As it can be seen, a considerable number of groups, representing more than $52 \%$ of the sample, have extreme values and outliers, which indicates the marked impact of "Other Comprehensive Income Items" on Net Income for all years and levels per size and also evidences a strong volatility across the period studied.

Table 6: Extreme Scores (*) and Outliers ( $($ ) Related to Group Size and Years

Consolidated values, expressed in percentage terms and calculated using the expression IMPACT OCI $=[\mathrm{OCI} /|\mathrm{NI}| \cdot \mathbf{1 0 0}]$

\begin{tabular}{|c|c|c|c|c|c|c|c|c|c|}
\hline \multirow{2}{*}{ SIZE } & \multirow{2}{*}{ GROUP } & \multirow{2}{*}{ COUNTRY } & \multicolumn{6}{|c|}{ YEARS OF THE PERIOD 1999-2004 } & \multirow{2}{*}{$\begin{array}{c}\text { Mean } \\
\text { 1999-2004 }\end{array}$} \\
\hline & & & 1999 & 2000 & 2001 & 2002 & 2003 & 2004 & \\
\hline \multirow{27}{*}{ Small } & BE Semiconductors & Netherlands & $300^{*}$ & 11 & -12 & $-35^{*}$ & -21 & -20 & 37 \\
\hline & Business Objects & France & -42 & -27 & -22 & $87 *$ & $176 \circ$ & 3 & 29 \\
\hline & $\begin{array}{c}\text { Compagnie Générale de } \\
\text { Géophysique }\end{array}$ & France & 6 & $55 \circ$ & $167 *$ & $-267 *$ & $-700 *$ & $-767 *$ & -251 \\
\hline & Converium Holding & Switzerland & -830 & $-48 \circ$ & -13 & $49 *$ & 110 & 6 & 4 \\
\hline & Cronos Group & Luxemburg & $50 \circ$ & -20 & 0 & 0 & 0 & 0 & 5 \\
\hline & Dassault Systèmes & France & 13 & 5 & 110 & -19 & -33 & -17 & -7 \\
\hline & Ducati Motor & Italy & 25 & 14 & 7 & -14 & $-100 \circ$ & $-50 \circ$ & -20 \\
\hline & Edap TMS & France & -17 & 670 & $86^{*}$ & 0 & -11 & 0 & 21 \\
\hline & Elan Corporation & Ireland & 15 & 1 & $9 \circ$ & -1 & 21 & -23 & 4 \\
\hline & Flamel Technologies & France & -29 & -10 & $-50 *$ & $67 *$ & $300^{*}$ & $78 *$ & 59 \\
\hline & Genesys & France & $75^{*}$ & 17 & 0 & 3 & 73 & 10 & 30 \\
\hline & Head & Netherlands & -15 & 17 & $-160 *$ & $-900 *$ & $183^{*}$ & $33 \circ$ & 160 \\
\hline & Icos Vision System & Belgium & $-100 *$ & -13 & 0 & 0 & -20 & -10 & -24 \\
\hline & Inficon Holding & Switzerland & -570 & 8 & $-37 *$ & $1000^{*}$ & 86 & $71^{*}$ & 179 \\
\hline & Iona Technologies & Ireland & $240^{*}$ & $-80^{*}$ & 0 & 0 & 0 & 0 & 27 \\
\hline & Millicom International & Luxemburg & $606^{*}$ & $-84 *$ & -180 & -12 & $508^{*}$ & -680 & 155 \\
\hline & Qiagen & Netherlands & -14 & 19 & $-23 *$ & $68 *$ & 53 & 26 & 22 \\
\hline & Rank Group & $\begin{array}{c}\text { United } \\
\text { Kingdom } \\
\end{array}$ & 1 & -3 & -3 & -98 & 57 & $58 \circ$ & 2 \\
\hline & SCOR & France & -780 & $69 \circ$ & -3 & -11 & -40 & $-38 \circ$ & -17 \\
\hline & Shire Pharmaceutical & $\begin{array}{c}\text { United } \\
\text { Kingdom }\end{array}$ & -7 & -22 & $-84 *$ & 21 & 43 & 20 & -5 \\
\hline & Tele2 & Sweden & -3 & $84 *$ & $282^{*}$ & $-70^{*}$ & -22 & -15 & 43 \\
\hline & Terra Networks & Spain & -1 & 1 & -7 & -20 & 20 & $117 *$ & 18 \\
\hline & Trikon Technologies & $\begin{array}{c}\text { United } \\
\text { Kingdom }\end{array}$ & -20 & -17 & $-33 *$ & 6 & 42 & 10 & -2 \\
\hline & Trinity Biotech & Ireland & 0 & $-50 \circ$ & 0 & 20 & -25 & 0 & -9 \\
\hline & Tsakos Energy Navigation & Greece & 0 & 0 & 0 & -250 & -2 & 2 & -4 \\
\hline & Van der Moolen Holding & Netherlands & 33 & 16 & 220 & $-323^{*}$ & -1460 & $-100^{*}$ & -83 \\
\hline & Wavecom & France & 0 & -7 & 220 & 0 & 8 & -4 & 3 \\
\hline
\end{tabular}


Table 6 continued

\begin{tabular}{|c|c|c|c|c|c|c|c|c|c|}
\hline \multirow[b]{2}{*}{ SIZE } & \multirow[b]{2}{*}{ GROUP } & \multirow[b]{2}{*}{ COUNTRY } & \multicolumn{6}{|c|}{ YEARS OF THE PERIOD 1999-2004 } & \multirow{2}{*}{$\begin{array}{l}\text { Mean } \\
1999- \\
2004 \\
\end{array}$} \\
\hline & & & 2001 & 2002 & 2003 & 2004 & 2005 & 2006 & \\
\hline \multirow{22}{*}{ Medium } & AEGON & Netherlands & 52 & 2 & 330 & -96 & -74 & -40 & -21 \\
\hline & Allied Irish Banks & Ireland & 36 & 46 & $60 *$ & -43 & -36 & -2 & 10 \\
\hline & Arcadis & Netherlands & 26 & 13 & 12 & $-330^{*}$ & 15 & $-153^{*}$ & -70 \\
\hline & ASM International & Netherlands & 91 & -1 & $83^{*}$ & -97 & -86 & -50 & -10 \\
\hline & Buhrmann & Netherlands & $108 \circ$ & $71 \circ$ & 14 & -31 & -19 & -73 & 12 \\
\hline & Endesa & Spain & 6 & -9 & $-54 \circ$ & -88 & 0 & -7 & -25 \\
\hline & Equant & Netherlands & -970 & -23 & -1 & 3 & 23 & 4 & -15 \\
\hline & Espirito Santo Financial Group & Luxemburg & 26 & $-76 \circ$ & -4 & 14 & $170^{*}$ & $85 \circ$ & 36 \\
\hline & Gemplus International & Luxemburg & 0 & -10 & -18 & 2 & -7 & $188^{*}$ & 26 \\
\hline & Havas & France & 92 & $-348 *$ & $76^{*}$ & -15 & -32 & $124 \circ$ & -59 \\
\hline & Hellenic Telecommnunications & Greece & 0 & -5 & 7 & -12 & 7 & $-98 \circ$ & -17 \\
\hline & ICTS International & Netherlands & $-200 *$ & $-200 *$ & -7 & 2 & 20 & 5 & -63 \\
\hline & Metso Corporation & Finland & 35 & 6 & -17 & $-409 *$ & -9 & $-700^{*}$ & -182 \\
\hline & Portugal Telecom & Portugal & -42 & $-531 *$ & $-531^{*}$ & $-574 *$ & -47 & -20 & -290 \\
\hline & Prudential & United Kingdom & -51 & 34 & $83^{*}$ & -76 & -1 & -11 & -4 \\
\hline & Publicis Groupe & France & 86 & $-106 \circ$ & 5 & $-1800^{*}$ & $-348^{*}$ & -33 & -336 \\
\hline & Reuters & $\begin{array}{c}\text { United } \\
\text { Kingdom }\end{array}$ & 94 & -51 & $-90^{*}$ & -105 & $-558^{*}$ & 7 & -117 \\
\hline & Rhodia & France & 41 & -13 & -37 & $-761 *$ & -16 & -9 & -133 \\
\hline & SGL Carbon & Germany & 26 & $600 *$ & 3 & $-315 \circ$ & -60 & -9 & 41 \\
\hline & Spirent & $\begin{array}{c}\text { United } \\
\text { Kingdom }\end{array}$ & $-333 *$ & -66 & 3 & -12 & $2300 *$ & 20 & 319 \\
\hline & Syngenta & Switzerland & $-627 *$ & -60 & $-65^{*}$ & 1460 & $173 *$ & 770 & -59 \\
\hline & Telefónica Móviles & Spain & -25 & 23 & $-296^{*}$ & -59 & -26 & -21 & -67 \\
\hline \multirow{23}{*}{ Big } & $\mathrm{ABB}$ & Switzerland & -9 & -6 & -79 & -23 & 16 & $-208^{*}$ & -52 \\
\hline & Alcatel & France & 126 & $126 \circ$ & -5 & -11 & -17 & -62 & 26 \\
\hline & Astrazeneca & United Kingdom & -10 & $-287 *$ & -105 & 123 & 156 & 70 & -9 \\
\hline & BAYER & Germany & 37 & $101 \circ$ & $152 \circ$ & -67 & -150 & $-419 *$ & -58 \\
\hline & Banco BilbaoVizcaya Argentaria & Spain & 188 & $-160 *$ & -196 & -171 & 5 & 9 & -54 \\
\hline & \begin{tabular}{|c|} 
Credit Suisse Group \\
\end{tabular} & Switzerland & 33 & 7 & $-552 *$ & -88 & -164 & -21 & -131 \\
\hline & Daimlerchrysler & Germany & 39 & 10 & -58 & -175 & 101 & $-82 \circ$ & -28 \\
\hline & Danone & France & 75 & 29 & $-271 \circ$ & -79 & -49 & -29 & -54 \\
\hline & Deutsche Bank & Germany & 30 & -17 & $-1701^{*}$ & $-1993 *$ & 74 & -30 & -606 \\
\hline & Fiat & Italy & $-561 *$ & -22 & -97 & -40 & -8 & -6 & -122 \\
\hline & Fresenius Medical Care & Germany & -24 & -27 & -2630 & -8 & 63 & 26 & -39 \\
\hline & Imperial Chemical Industries & United Kingdom & -7 & -9 & $-2057 *$ & $-3714 *$ & -124 & -5 & -986 \\
\hline & Lafarge & France & 63 & -28 & -52 & $-397 \circ$ & -100 & -7 & -87 \\
\hline & Royal \& Sun Alliance & United Kingdom & -43 & -57 & -2630 & -125 & -71 & $120 \circ$ & -73 \\
\hline & Royal KPN & Netherlands & 2510 & -24 & 30 & 0 & -8 & -7 & 40 \\
\hline & Santander Central Hispano & Spain & 2610 & $162 *$ & -231 & -3980 & 45 & -9 & -28 \\
\hline & STMicrolectronics & Switzerland & -58 & -12 & -75 & 142 & $349 \circ$ & $82 \circ$ & 71 \\
\hline & Telefónica & Spain & $256 \circ$ & $-106 \circ$ & -90 & -175 & -18 & 18 & -19 \\
\hline & Thomson Multimedia & France & $532 *$ & $-240 *$ & -75 & -184 & $-571 *$ & -21 & -93 \\
\hline & TPGH & Netherlands & 7 & -3 & 1 & -9 & -27 & $-83 \circ$ & -19 \\
\hline & Vivendi & France & 180 & $129 *$ & -181 & -10 & -62 & 49 & 18 \\
\hline & Volvo & Sweden & -6 & $-98 \circ$ & -32 & -8 & 75 & -27 & -16 \\
\hline & WPP Group & United Kingdom & 12 & $-114 \circ$ & -42 & 75 & 79 & 41 & 8 \\
\hline
\end{tabular}

Source: authors' calculations, based on the database and the box plots obtained with SPSS v.15.

\section{Impact By Industries}

Finally, we want to study the effects of "Other Comprehensive Income" on Net Income by industries based on the Industry Classification Benchmark (ICB —-Dow Jones Indexes and FTSE-), in which, as shown in Table 7, 
we integrated each one of the corporate groups listed in NYSE and NASDAQ, paying attention to the nature of the activities they carry out.

Table 7: Groups by Industries According to ICB

\begin{tabular}{|c|c|c|}
\hline INDUSTRY & $\begin{array}{c}\text { Number of } \\
\text { corporate groups }\end{array}$ & $\begin{array}{c}\text { Percentage of groups of the sample out of the total amount of } \\
\text { European listed companies in NYSE and NASDAQ on 31 } \\
\text { December 2004 assigned to each industry }\end{array}$ \\
\hline Consumer Goods & 12 & $39 \%$ \\
\hline Financials & 16 & $59 \%$ \\
\hline Industrials & 22 & $69 \%$ \\
\hline Health Care & 19 & $61 \%$ \\
\hline Basic Materials & 9 & $53 \%$ \\
\hline Oil \& Gas & 10 & $67 \%$ \\
\hline Consumer Services & 10 & $44 \%$ \\
\hline Technology & 17 & $59 \%$ \\
\hline Telecommunications & 17 & $61 \%$ \\
\hline Utilities & 4 & $40 \%$ \\
\hline Total............................136 & $56 \%$ \\
\hline
\end{tabular}

Source: authors' calculations, based on the database and ICB available at http://www.icbenchmark.com.

In Table 8 and in Graphic 4, we can see that, on average, the impact of "Other Comprehensive Income" compared to Net Income has been quite unequal for industries. Thus, the least affected industries are Health Care, Industrials and Telecommunications; the first two with positive impact, whereas the last has registered a positive value. Nevertheless, sufficient sectors have experienced noticeable negative effects, among which it is worth noting Basic Materials, Consumer Services, Financials, Oil \& Gas and Utilities.

Table 8: Impact of Means by Industries of “Other Comprehensive Income” on Net Income

Consolidated values, expressed in percentage terms and calculated using the expression IMPACT OCI $=[\mathrm{OCI} /|\mathrm{NI}| \cdot \mathbf{1 0 0}]$

\begin{tabular}{|c|c|r|r|r|r|r|r|}
\hline INDUSTRY & $\mathbf{1 9 9 9}$ & $\mathbf{2 0 0 0}$ & $\mathbf{2 0 0 1}$ & $\mathbf{2 0 0 2}$ & $\mathbf{2 0 0 3}$ & $\mathbf{2 0 0 4}$ & $\begin{array}{c}\text { Average } \\
\mathbf{1 9 9 9}-2004\end{array}$ \\
\hline Consumer Goods & 24.50 & -23.59 & -57.27 & 17.42 & -54.06 & -13.95 & -17.83 \\
\hline Financials & 21.88 & -0.78 & -175.82 & -216.90 & -2.93 & -0.13 & -62.45 \\
\hline Industrials & -1.65 & 24.11 & -10.28 & -39.46 & 105.63 & -47.04 & 5.22 \\
\hline Health Care & -3.20 & -16.67 & -24.77 & 14.748 & 37.15 & 11.08 & 3.06 \\
\hline Basic Materials & -40.55 & -9.14 & -245.49 & -529.23 & -17.03 & -41.11 & -147.09 \\
\hline Oil \& Gas & 1.28 & 6.50 & 0.46 & -66.40 & -69.36 & -93.16 & -36.78 \\
\hline Consumer Services & 30.38 & -66.95 & -22.90 & -220.42 & -109.97 & -7.05 & -66.15 \\
\hline Technology & 26.06 & -2.93 & -5.39 & 5.34 & 31.30 & 6.56 & 10.16 \\
\hline Telecommunications & 69.49 & -39.93 & -36.30 & -61.84 & 28.93 & -14.01 & -8.94 \\
\hline Utilities & -6.89 & 1.51 & -30.60 & -70.69 & -9.79 & 2.49 & -190.00 \\
\hline
\end{tabular}

Source: authors' calculations, based on the database and SPSS v.15. 
Graphic 4: Profile of the Impact of Means by Industries of "Other Comprehensive Income" on Net Income

\section{Consolidated values, expressed in percentage terms and calculated using the expression IMPACT OCI $=[\mathrm{OCI} /|\mathrm{NI}| \cdot \mathbf{1 0 0}]$}

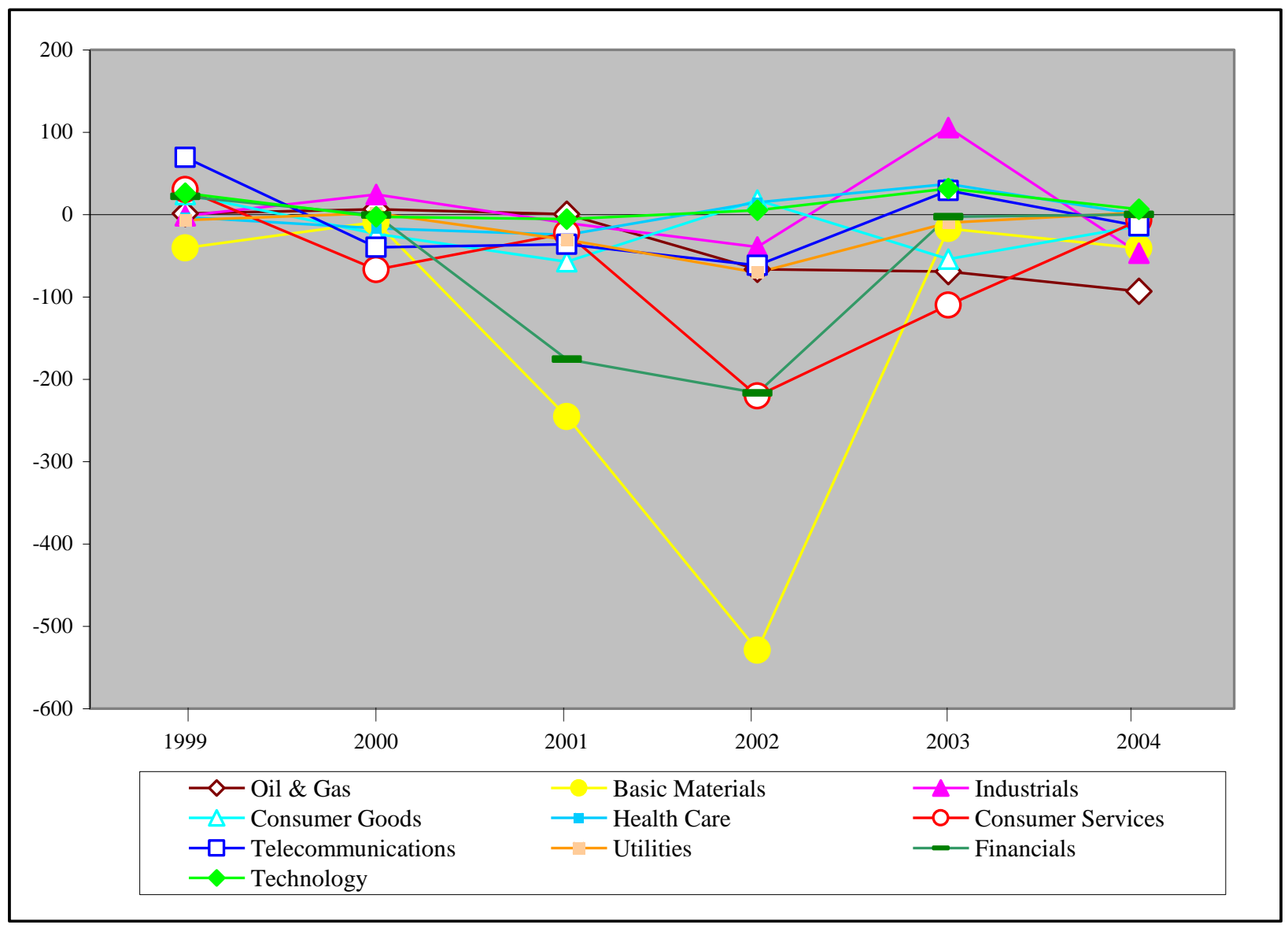

Source: authors' calculations, based on the database and SPSS v.15.

Consistent with the results presented in this work, one can see that the stock-exchange crisis of the early 2000 's, together with the unfavorable exchange rates experienced by many corporate groups, has caused a marked negative impact on "Other Comprehensive Income" compared to Net Income for many industries. We are faced with a phenomenon that, in the context studied, generally affects corporate groups independently of the nature of the activities they carry out.

On the other hand, we can see in Table 9 that a considerable number of groups for all years and nine industries, representing more than $49 \%$ of the sample, have extreme values and outliers. The results taken together with those obtained in Table 6 indicate the marked impact of "Other Comprehensive Income Items" on Net Income and also evidences a strong volatility across the period studied. 
Table 9: Extreme Scores (*) and Outliers ( $($ ) Related to Industries and Years

Consolidated values, expressed in percentage terms and calculated using the expression IMPACT OCI $=[$ OCI $/|\mathrm{NI}| \cdot \mathbf{1 0 0}]$

\begin{tabular}{|c|c|c|c|c|c|c|c|c|c|}
\hline \multirow{2}{*}{ INDUSTRY } & \multirow{2}{*}{ GROUP } & \multirow{2}{*}{ COUNTRY } & \multicolumn{6}{|c|}{ YEARS OF THE PERIOD 1999-2004 } & \multirow{2}{*}{$\begin{array}{c}\text { Mean } \\
1999- \\
2004\end{array}$} \\
\hline & & & 1999 & 2000 & 2001 & 2002 & 2003 & 2004 & \\
\hline \multirow{7}{*}{$\begin{array}{l}\text { Consumer } \\
\text { Goods }\end{array}$} & Daimlerchrysler & Germany & 39 & 10 & -58 & -1750 & 101 & -820 & -28 \\
\hline & Danone & France & 75 & 29 & $-271 \circ$ & -79 & -49 & -29 & -54 \\
\hline & Fiat & Italy & $-561 *$ & -22 & -97 & -40 & -8 & -6 & -122 \\
\hline & Gallaher Group & United Kingdom & -7 & 1 & 2 & -58 & $8^{\circ}$ & $50 \circ$ & -1 \\
\hline & Head & Netherlands & -15 & 17 & -160 & $900^{*}$ & 183 & 33 & 160 \\
\hline & Thomson Multimedia & France & $532 *$ & $-240^{*}$ & -75 & $-184 \circ$ & $-571^{*}$ & -21 & -93 \\
\hline & Volvo & Sweden & -6 & -980 & -32 & -8 & 75 & -27 & -16 \\
\hline \multirow{6}{*}{ Financials } & Banco BilbaoVizcaya Argentaria & Spain & $188 \circ$ & $-160 \circ$ & -196 & -171 & 5 & 9 & -54 \\
\hline & Deutsche Bank & Germany & 30 & -17 & $-1701 *$ & $-1993 *$ & 74 & -30 & -606 \\
\hline & Espirito Santo Financial Group & Luxemburg & 26 & -76 & -4 & 14 & 170 & $85 \circ$ & 36 \\
\hline & Royal \& Sun Alliance & United Kingdom & -43 & -57 & -263 & -125 & -71 & $120^{*}$ & -73 \\
\hline & Santander Central Hispano & Spain & 2610 & $162 \circ$ & -231 & $-398 \circ$ & 45 & -9 & -28 \\
\hline & Van der Moolen Holding & Netherlands & 33 & 16 & 22 & -323 & -146 & $-100 \circ$ & -83 \\
\hline \multirow{11}{*}{ Industrials } & $\mathrm{ABB}$ & Sweden & -9 & -6 & $-79 \circ$ & -23 & 16 & -2080 & -52 \\
\hline & Arcadis & Netherlands & 26 & 13 & 12 & $-330 *$ & 15 & -1530 & -70 \\
\hline & ASM International & Netherlands & 91 & -1 & $83 \circ$ & -97 & -86 & -50 & -10 \\
\hline & Buhrmann & Netherlands & 1080 & 710 & 14 & -31 & -19 & -73 & 12 \\
\hline & CNH Global & Netherlands & -950 & -35 & -75 & -44 & $189 \circ$ & 37 & -4 \\
\hline & Gemplus International & Luxemburg & 0 & -10 & -18 & 2 & -7 & $188 \circ$ & 26 \\
\hline & Inficon Holding & Switzerland & -57 & 8 & -37 & $1000^{*}$ & 86 & 71 & 179 \\
\hline & Lafarge & France & 63 & -28 & -52 & $-397 *$ & -100 & -7 & -87 \\
\hline & Metso Corporation & Finland & 35 & 6 & -17 & $-409 *$ & -9 & $-700^{*}$ & -182 \\
\hline & SGL Carbon & Germany & 26 & $600 *$ & 3 & -3150 & -60 & -9 & 41 \\
\hline & Spirent & United Kingdom & $-333^{*}$ & -66 & 3 & -12 & $2300 *$ & 20 & 319 \\
\hline \multirow{10}{*}{ Health Care } & Astrazeneca & United Kingdom & -10 & $-287^{*}$ & $-105^{*}$ & $123^{*}$ & $156 \circ$ & $70 \circ$ & -9 \\
\hline & Edap TMS & France & -17 & $67 *$ & $86^{*}$ & 0 & -11 & 0 & 21 \\
\hline & Flamel Technologies & France & -29 & -10 & $-50 \circ$ & $67 \circ$ & $300^{*}$ & 78 & 59 \\
\hline & Fresenius Medical Care & Germany & -24 & -27 & $-263^{*}$ & -8 & 63 & 26 & -39 \\
\hline & Novartis & Switzerland & 410 & 5 & -15 & -10 & 58 & 36 & 19 \\
\hline & Qiagen & Netherlands & -14 & 19 & -23 & $68 \circ$ & 53 & 26 & 22 \\
\hline & Schering & Netherlands & $47 *$ & 16 & -12 & -31 & -36 & -20 & -6 \\
\hline & Shire Pharmaceutical & United Kingdom & -7 & -22 & $-84^{*}$ & 21 & 43 & 20 & -5 \\
\hline & Smith \& Nephew & United Kingdom & 4 & -3 & -1 & $-45 \circ$ & -14 & -12 & -12 \\
\hline & Trinity Biotech & Ireland & 0 & $-50^{*}$ & 0 & 20 & -25 & 0 & -9 \\
\hline \multirow{4}{*}{$\begin{array}{c}\text { Basic } \\
\text { Materials }\end{array}$} & BAYER & Germany & 37 & 1010 & $152^{*}$ & -67 & $-150 \circ$ & $-419 *$ & -58 \\
\hline & Imperial Chemical Industries & United Kingdom & -7 & -9 & $-2057^{*}$ & $-3714^{*}$ & -124 & -5 & -986 \\
\hline & Rhodia & France & 41 & -13 & -37 & $-761 *$ & -16 & -9 & -133 \\
\hline & Syngenta & Switzerland & $-627 *$ & -60 & $-65^{*}$ & $146 \circ$ & $173 *$ & $77 \circ$ & -59 \\
\hline \multirow{4}{*}{ Oil \& Gas } & $\begin{array}{c}\text { Compagnie Générale de } \\
\text { Géophysique }\end{array}$ & France & 6 & $55^{*}$ & $167^{*}$ & -2670 & $-700^{*}$ & $-767 *$ & -251 \\
\hline & British Petroleum & United Kingdom & -20 & -250 & -36 & 26 & 53 & 2 & 0 \\
\hline & Repsol YPF & Spain & 18 & 16 & -1160 & -146 & -65 & -18 & -52 \\
\hline & Technip & France & 4 & 1 & 10 & -57 & 90 & $-88 \circ$ & -7 \\
\hline \multirow{4}{*}{$\begin{array}{l}\text { Consumer } \\
\text { Services }\end{array}$} & Havas & France & 92 & $-348 \circ$ & 76 & -15 & -32 & -124 & -59 \\
\hline & ICTS International & Netherlands & $-200 \circ$ & -200 & -7 & 2 & 20 & 5 & -63 \\
\hline & Publicis Groupe & France & 88 & -106 & 5 & $-1800^{*}$ & -348 & -33 & -366 \\
\hline & Vivendi & France & 180 & 129 & $-181 \circ$ & -10 & -62 & 49 & 18 \\
\hline \multirow{11}{*}{ Technology } & Alcatel & France & 126 & $126 \circ$ & -5 & -11 & -17 & -62 & 26 \\
\hline & BE Semiconductors & Netherlands & $300^{*}$ & 11 & -12 & $-35 \circ$ & -21 & -20 & 37 \\
\hline & Business Objects & France & $-42 \circ$ & -27 & $-22 *$ & $87 *$ & $176^{*}$ & 3 & 29 \\
\hline & Dassault Systèmes & France & 13 & 5 & 110 & -19 & -33 & -17 & -7 \\
\hline & Equant & Netherlands & $-97 *$ & -23 & -1 & 3 & 23 & 4 & -15 \\
\hline & Icos Vision System & Belgium & $-100 *$ & -13 & 0 & 0 & -20 & -10 & -24 \\
\hline & Iona Technologies & Ireland & $240 *$ & $-80^{*}$ & 0 & 0 & 0 & 0 & 27 \\
\hline & SAP & Germany & $50 \circ$ & -28 & -2 & $-60^{*}$ & -7 & -8 & -9 \\
\hline & Sapiens International & Netherlands & -8 & -2 & 0 & $20 \circ$ & 50 & 20 & 13 \\
\hline & Terra Networks & Spain & -1 & 1 & -7 & -20 & 20 & $117^{*}$ & 18 \\
\hline & Wavecom & France & 0 & -7 & $22 *$ & 0 & 8 & -4 & 3 \\
\hline
\end{tabular}


Table 9 continued

\begin{tabular}{|c|c|c|c|c|c|c|c|c|c|}
\hline \multirow[b]{2}{*}{ INDUSTRY } & \multirow[b]{2}{*}{ GROUP } & \multirow[b]{2}{*}{ COUNTRY } & \multicolumn{6}{|c|}{ YEARS OF THE PERIOD 1999-2004 } & \multirow{2}{*}{$\begin{array}{c}\text { Mean } \\
1999 . \\
2004\end{array}$} \\
\hline & & & 1999 & 2000 & 2001 & 2002 & 2003 & 2004 & \\
\hline \multirow{10}{*}{$\begin{array}{l}\text { Tele- } \\
\text { communications }\end{array}$} & France Télécom & France & 101 & -36 & 6 & -16 & $149^{*}$ & 21 & 38 \\
\hline & Genesys & France & 75 & 17 & 0 & 3 & 730 & 10 & 30 \\
\hline & Hellenic Telecommnunications & Greece & 0 & -5 & 7 & -12 & 7 & $-98^{*}$ & -17 \\
\hline & Millicom International & Luxemburg & $606^{*}$ & -84 & -18 & -12 & $508 *$ & -680 & 155 \\
\hline & Portugal Telecom & Portugal & -42 & $-528 *$ & $-531 *$ & $-574 *$ & -47 & -20 & -290 \\
\hline & Royal KPN & Netherlands & 2510 & -24 & $30 \circ$ & 0 & -8 & -7 & 40 \\
\hline & Telefónica & Spain & 2560 & -1060 & -90 & -1750 & -18 & 18 & -19 \\
\hline & Telefónica Móviles & Spain & -25 & 23 & $-296 *$ & -59 & -26 & -21 & -67 \\
\hline & Telenor & Norway & 1 & -51 & 2 & -79 & $49 \circ$ & -37 & -19 \\
\hline & Tele2 & Sweden & -3 & 840 & $282^{*}$ & -70 & -22 & -15 & 43 \\
\hline
\end{tabular}

Source: authors' calculations, based on the database and the box plots obtained with SPSS v.15.

\section{CONCLUSIONS}

We have studied the impact of "Other Comprehensive Income" on Net Income using a sample of 136 corporate companies on the European continent listed in NYSE and NASDAQ during the period 1999-2004 and, on average, have detected noticeable negative effects on the group considering the analysis detailed by size and industries, essentially motivated by the stock-exchange crisis of the early 2000's and by unfavorable exchange rates, particularly between the Euro and the U.S. dollar.

All of this reveals the greater connection of Comprehensive Income with the reality of the markets than Net Income, which presumes that SFAS 130 issued by the FASB contributes to the increase of the relevance of the financial information in the results area. This is especially true for investors, considered in the Conceptual Framework as reference users, as they can thus improve their decision making for contribution to the most efficient allocation of resources in the markets of international capitals in an economy that is more and more globalized.

\section{AUTHOR INFORMATION}

F. Sousa Fernández. PhD. Associate Professor of Financial Economy and Accounting at the University of Cantabria (Spain). Doctoral Thesis: Comprehensive Income in the Context of International Financial Information: Conceptual Framework, Comparative Analysis on Standards and an Empirical Research for European Groups Listed in NYSE and NASDAQ. He has won several awards for articles derived from research in Comprehensive Income, granted by the most prestigious Associations and Organizations in the field of Accounting and Business Administration in Spain, such as AECA, ICAC, ASEPUC and CEF.

\section{NOTES}

1 The SEC has adopted new rules to allow foreign private issuers to use financial statements prepared in accordance with IASB GAAP without the requirement to reconcile those financial statements to U.S. GAAP.

2 Foster and May (1996); Jones and Wilson (2000); Thomson et al. (2002) and Pandit and Phillips (2004); Pandit et al. (2006), in regards to the adoption of SFAS 130, describe the problems related to the disclosure of Comprehensive Income, and we counted with references to real data from U.S. companies.

3 One will notice that the sum of the averages of these four items (-26.69) does not coincide with the global average of -25.36 for the entire study period, which we collected in Table 2 a difference of 1.33 ; this corresponds to the "other" item, which we have not considered in the analysis as it obviously does not represent relative importance, in addition to integrating items of a very different nature that certain corporate groups considered suitable to disclose.

4 In order to determine the relative discrepancy, we have considered the mathematical expression IMPACT OCI = $[\mathrm{OCI} /|\mathrm{NI}| \cdot 100]$ in which each one of the components included in "Other Comprehensive Income" has been considered independently in the numerator. 


\section{REFERENCES}

1. Financial Accounting Standards Board, FASB, SFAS 130, Reporting Comprehensive Income, 1997, available in http:///www.fasb.org [accessed on July 14, 2008].

2. Financial Accounting Standards Board, FASB, SFAC 6, Elements of Financial Statements - a replacement of FASB Concepts Statement No. 3 (incorporating an amendment of FASB Concepts Statement No. 2), 1985, available in http:///www.fasb.org [accessed on July 14, 2008].

3. Foster, N. and N. L. Hall, Reporting Comprehensive Income, Shedding more light on items reported directly to equity, CPA Journal, October, available in http://luca.com/CPAJournal/1996/1096/features/ reporting.htm, [Accessed on August 12, 2008].

4. International Accounting Standards Board, IAS 1, Presentation of Financial Statements, in Improvement to International Accounting Standard, (revised in 2007), IASB, London, 2003.

5. Jones, J. P. and A. C. Wilson, The Effect of Accounting for Derivatives on Other Comprehensive Income, The CPA Journal, March. pp, 54-56, 2000.

6. Pandit, G. M. and J. J. Phillips, Comprehensive Income: Reporting Preferences of Public Companies, The CPA Journal, November, pp. 40-41, 2004.

7. Pandit, G. M; Allen Rubenfield, C. and J. J. Phillips, Current NASDAQ Corporation Methods of Reporting Comprehensive Income, American Journal of Business, Vol. 21, No. 1, pp. 13-19, 2006.

8. Thompson, J. H.; Womack, C.; Hodge, T. G. and T. L. Mccoy, A Survey of Fortune 500 Companies' Reporting Comprehensive Income, Northeast Regional Meeting of the American Accounting Association, April 2002, available on the Web of the AAA at http://aaahq.org/northeast/Abstracts\%5cThompson.pdf, [accessed on October, 22, 2003].

9. U.S. Securities and Exchange Commission, SEC, the Electronic Data Gathering, Analysis, and Retrieval system (EDGAR), available in http://www.sec.gov/edgar/searchedgar/companysearch.html [accessed from December 2007 till July 2008]. 


\section{NOTES}

